ACTA AGROBOTANICA

Vol. 61 (2): 229-238

2008

\title{
THE INFLUENCE OF DIFFERENT HERBICIDE DOSES ON WEED INFESTATION OF WINTER TRITICALE CULTIVATED IN MONOCULTURE
}

\author{
Piotr Kraska
}

\begin{abstract}
Department of Agricultural Ecology, University of Life Sciences in Lublin, Akademicka 13, 20-950 Lublin, Poland e-mail: piotr.kraska@up.lublin.pl
\end{abstract}

Received: 27.11.2007

S u m m a r y

The study was carried out in 2003-2005 in the Bezek Experimental Farm (University of Life Sciences in Lublin). The experimental field was situated on light loamy sand soil. The phosphorus content in soil was high, in potassium medium, in magnesium low. The humus content was $1.2 \%$. The experiment was carried out in randomized blocks in three replications. The aim of the investigation was to compare three doses of herbicides in winter triticale canopy (Janko cv., Woltario cv., Krakowiak cv.) cultivated in monoculture. The herbicides Atlantis $04 \mathrm{WG}$ and Factor $365 \mathrm{EC}$ were applied at full recommended doses $\left(200{\mathrm{~g} \times h \mathrm{~h}^{-1}}^{-1}\right)$, at doses reduced to $75 \%$ and $50 \%$. The control was not treated with the herbicides. The weed infestation level was determined by means of the quantitative-weighting method at two dates: the first one at the 6th week after herbicide application and the second one before harvest. The density of weed individuals was counted; the species composition and airdry biomass of above-ground parts were estimated from the randomly selected areas of $1 \mathrm{~m} \times 0.25 \mathrm{~m}$ at four sites of each plot. The density of weeds and weed air dry weight were statistically analysed by means of variance analysis, and the mean values were estimated with Tukey's confidence intervals $(\mathrm{p}=0.05)$.

It was found that the number of weeds and air dry mass of weeds in the control were significantly higher in comparison with the herbicide treated objects. The application of different doses of herbicides did not differentiate significantly the weed infestation level in the winter triticale canopy. Viola arvensis, Matricaria maritima, Chenopodium album and Apera spicaventi were dominant species of weeds in the winter triticale canopy. The selection of cultivars did not influence the canopy weed infestation level.

Key words: herbicide doses, cultivars, winter triticale, weed infestation

\section{INTRODUCTION}

Weeds significantly reduce yields of crop plants and affect yield quality. They compete with the crop plant for room, light, water and nutrients; they can even lead to complete choking of plants. For hundred of years, the fight against weeds has been mainly based on their control by using mechanical and agrotechnical methods. A breakthrough took place when chemical plant protection agents were discovered (A d a mc zewski, 2000).

A reduction in herbicide doses allows to cut costs of weed control, to mitigate the risk of environmental contamination, as well as to reduce permissible levels of residues of biologically active substances in cereal products (Rola et al. 1997; Do maradzki and Rola, 2000; D o mara dzki and S a d ow ski, 2002). The application of a proper dose of a herbicide must take into account its weed-killing effectiveness in given conditions, the maintenance of selectivity for the protected plant and consumer safety (S t r e i b i g, 1989).

A reduction in herbicide doses also involves a change in the perception of the problem of weed control. The aim of this control should not be the total destruction of all weeds growing in a crop canopy but such reduction of their occurrence and weakening of the form so that they do not pose a threat to the crop plant (D o m aradzki and R o la, 1999). Proven et al. (1991) have found that the application of reduced herbicide rates is of special significance at a low level of cereal canopy weed infestation.

Davies and Whiting (1989), Domaradzki and Rola (2001, 2004), Domaradzki (2006) and K r a s k a (2006) have demonstrated that it is possible to reduce herbicide doses from $20 \%$ to $50 \%$ without a significant reduction in yielding levels of winter and spring cereal crops, at the same time maintaining the required weed-killing effectiveness. They have also found that the application of herbicides at reduced doses gives the best effects in fields where weeds occur at early development stages. Very good results can be obtained on plantations with low weed intensity and in controlling weeds sensitive to a particular herbicide. 


\section{MATERIALS AND METHODS}

The field experiment was carried out in the years 2003-2005 in the Bezek Experimental Farm near Chełm, Poland, owned by the University of Life Sciences in Lublin. In the two-factor experiment conducted in randomized blocks in three replications, the effect of three herbicide doses in the winter triticale Tricicale rimpaui Wittm. canopy (Janko cv., Woltario cv., Krakowiak cv.) was compared. The herbicides were applied at full recommended doses, reduced to $75 \%$ and at doses reduced by half. Herbicide untreated plots were the control. The plot size was $12 \mathrm{~m}^{2}$. The results were presented as three-year means.

The experimental field was located on incomplete podzolic soil lying on marl substrate with the granulometric composition of light and strong loamy sand. This soil is classified as IVb evaluation class and good rye complex. Soil nutrient availability in terms of available phosphorus was high, in potassium medium, in magnesium low. Expressed in $\mathrm{mg} \times \mathrm{kg}^{-1}$, it was as follows, respectively: $\mathrm{P}_{2} \mathrm{O}_{5}-171 ; \mathrm{K}_{2} \mathrm{O}-120 ; \mathrm{Mg}-22$. The humus content was $1.2 \%$. The soil reaction was slightly acid, and the $\mathrm{pH}$ in $1 \mathrm{~mol} \mathrm{KCl}$ was 6.0.

Tillage was done following generally accepted agricultural practice recommendations. Winter triticale was a forecrop. After harvesting the forecrop, skimming and harrowing were performed. 3 weeks before sowing, pre-sowing ploughing was carried out. Before sowing, cultivator tillage with harrowing was performed. Seeds dressed with Panoctine 300 LS (a biologically active substance - guazatine in the form of acetate) were sown at an amount of 5 million seeds per ha-1 with the row spacing of $12 \mathrm{~cm}$. Mineral fertiliser doses were as follows: $\mathrm{N}-120 \mathrm{~kg} \times \mathrm{ha}^{-1} ; \mathrm{P}_{2} \mathrm{O}_{5}$

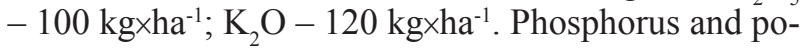
tassium fertilisers as well as $30 \mathrm{~kg} \mathrm{~N} \mathrm{ha}^{-1}$ were applied pre-sowing. The remaining part of the nitrogen dose was applied before vegetation start at the rate of 60 $\mathrm{kg} \times \mathrm{ha}^{-1}$ and $30 \mathrm{~kg} \times \mathrm{ha}^{-1}$ at the shooting stage. In addition, the following plant protection agents were used:

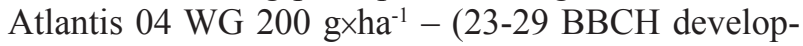
ment stages*) + Actirob 842 EC $1.01 \times$ ha $^{-1}$ - basic dose, Factor 365 EC $1.01 \times \mathrm{ha}^{-1}-\left(23-29^{*}\right)$ - basic dose, Alert 375 SC $1.01 \times \mathrm{ha}^{-1}-\left(26-29^{*}\right)$, Tango 500 SC 0.8 $1 \times \mathrm{ha}^{-1}-\left(51-56^{*}\right)$, Terpal C 460 SL $2.51 \times \mathrm{ha}^{-1}-(32-$ $\left.39^{*}\right)$. The herbicides Atlantis $04 \mathrm{WG}$ (containing two active substances: mesosulfuron-methyl $30 \mathrm{~g} \times \mathrm{kg}^{-1}+$ iodosulfuron-methyl-sodium $6{\mathrm{~g} \times \mathrm{kg}^{-1}}$ and as a safener

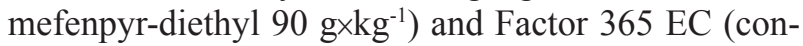

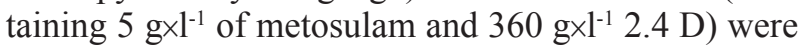
applied jointly. In the experiment, the adjuvant Actirob 842 EC was applied (containing $842 \mathrm{~g}$ of rape oil methyl ester in 1 litre).

Canopy weed infestation was determined twice using the quantitative-weighting method. The first time was 6 weeks after herbicide treatment, the second time before winter triticale harvesting. The number of individuals, species composition and air-dry mass of above-ground parts of weeds were determined from the test areas surrounded by a frame of $1 \mathrm{~m} \mathrm{x} 0.25 \mathrm{~m}$ in four randomly selected sites of each plot, in accordance with the recommendations given in the paper of B a d ow s ki et al. (2001).

The obtained results were statistically analysed by means of variance analysis. The mean values were compared by means of the least significant differences using the Tukey test.

\section{RESULTS}

The weed infestation level of winter triticale canopy was significantly modified by the application of herbicides. At both dates of weed infestation assessment, it was found that there was a significantly lower number of dicotyledonous and monocotyledonous weeds and their total number as well as smaller air-dry mass of weeds in the herbicide-treated plots compared to the control in which no herbicides were applied (Tab. 1).

The selection of triticale cultivars did not significantly change the canopy weed infestation level at both assessment dates. However, a tendency towards the occurrence of a larger total number of weeds in the canopy of 'Woltario' cv. was noticeable before the harvest (Tab. 2).

The largest number of weed species at both dates of weed infestation assessment was found in the control compared to the herbicide-treated plots (Tab. 3, Tab. 4). In the herbicide-treated plots, those in which a half of herbicide doses was applied were characterised by the greatest species diversity, whereas those where the full recommended dose was applied had the lowest species diversity. At the first date of weed infestation assessment, the applied herbicides completely eliminated the following weed species, compared to the herbicide untreated control: Chenopodium album, Cerastium holosteoides, Conyza canadensis, Spergula arvensis, Sonchus arvensis, Anchusa arvensis and Raphanus raphanistrum. At the same time, they reduced to a large extent the occurrence of Matricaria maritima and Apera spica-venti (Tab. 3). But before winter triticale harvest, the used herbicides eliminated Spergula arvensis, Gypsophila muralis and Anchusa arvensis. At the same time, out of the species occurring in great numbers, they markedly reduced the number of Chenopodium album, Matricaria maritime and in the first place Apera spica-venti (Tab. 4).

From the group of dicotyledonous species, Viola arvensis, Matricaria maritima, Veronica arvensis and Chenopodium album occurred most numerously in the 
Table 1

Weed infestation elements in canopy of x Triticale rimpaui Wittm. per $1 \mathrm{~m}^{2}$ in dependence on herbicide doses, mean figures in the years 2003-2005.

\begin{tabular}{|c|c|c|c|c|c|}
\hline \multirow{3}{*}{ Number and dry matter of weeds } & \multicolumn{5}{|c|}{ Herbicide doses } \\
\hline & $A^{*}$ & $\mathrm{~B}$ & $\mathrm{C}$ & $\mathrm{D}$ & \multirow{2}{*}{$\mathrm{LSD}_{0.05}$} \\
\hline & \multicolumn{4}{|c|}{$1^{\text {st }}$ date } & \\
\hline Number of dicotyledonous weeds & 52.0 & 13.2 & 13.7 & 19.5 & 9.9 \\
\hline Number of monocotyledonous weeds & 19.7 & 1.1 & 2.4 & 3.0 & 6.0 \\
\hline Total weeds & 71.7 & 14.3 & 16.1 & 22.5 & 11.3 \\
\hline \multirow[t]{2}{*}{ Air dry matter of weed in $\mathrm{g} \times \mathrm{m}^{-2}$} & 53.0 & 4.4 & 3.7 & 8.5 & 9.9 \\
\hline & \multicolumn{4}{|c|}{$2^{\text {nd }}$ date } & \\
\hline Number of dicotyledonous weeds & 25.0 & 13.2 & 12.3 & 23.6 & 12.0 \\
\hline Number of monocotyledonous weeds & 77.9 & 12.7 & 10.4 & 10.7 & 16.5 \\
\hline Total weeds & 102.9 & 25.9 & 22.7 & 34.3 & 21.6 \\
\hline Air dry matter of weed in $\mathrm{g} \times \mathrm{m}^{-2}$ & 75.3 & 6.4 & 4.5 & 9.4 & 17.9 \\
\hline $\begin{array}{l}* \mathrm{~A}-\text { control (without herbicides) } \\
\mathrm{B}-\text { full dose of herbicides } \\
\mathrm{C}-75 \% \text { dose of herbicides } \\
\mathrm{D}-50 \% \text { dose of herbicides }\end{array}$ & & & & & \\
\hline
\end{tabular}

Table 2

Weed infestation elements in canopy of x Triticale rimpaui Wittm. per $1 \mathrm{~m}^{2}$ in dependence on cultivars, mean figures in the years 2003-2005.

\begin{tabular}{|c|c|c|c|c|}
\hline \multirow{3}{*}{ Number and dry matter of weeds } & \multicolumn{4}{|c|}{ Herbicide doses } \\
\hline & Janko & Woltario & Krakowiak & \multirow{2}{*}{$\operatorname{LSD}_{0.05}$} \\
\hline & \multicolumn{3}{|c|}{$1^{\text {st }}$ date } & \\
\hline Number of dicotyledonous weeds & 23.9 & 25.0 & 24.5 & $\mathrm{~ns}^{*}$ \\
\hline Number of monocotyledonous weeds & 8.1 & 5.0 & 6.7 & ns* \\
\hline Total weeds & 32.0 & 30.0 & 31.2 & ns* \\
\hline \multirow[t]{2}{*}{ Air dry matter of weed in $\mathrm{g} \times \mathrm{m}^{-2}$} & 19.9 & 15.8 & 16.6 & $\mathrm{~ns}^{*}$ \\
\hline & \multicolumn{3}{|c|}{$2^{\text {nd }}$ date } & \\
\hline Number of dicotyledonous weeds & 16.4 & 20.1 & 19.1 & $\mathrm{~ns}^{*}$ \\
\hline Number of monocotyledonous weeds & 29.6 & 30.0 & 24.3 & ns* \\
\hline Total weeds & 46.0 & 50.1 & 43.4 & ns* \\
\hline Air dry matter of weed in $\mathrm{g} \times \mathrm{m}^{-2}$ & 20.0 & 23.9 & 27.7 & $\mathrm{~ns}^{*}$ \\
\hline
\end{tabular}

$*_{\mathrm{ns}}-$ not significant 
Table 3

Species composition and the number of weeds per $1 \mathrm{~m}^{2}$ of $\mathrm{x}$ Triticale rimpaui Wittm. canopy at the first date weed infestation assessment in dependence on herbicide doses, mean figures in the years 2003-2005.

\begin{tabular}{|c|c|c|c|c|}
\hline \multirow{2}{*}{ Species } & \multicolumn{4}{|c|}{ Herbicide doses } \\
\hline & $* \mathrm{~A}$ & $\mathrm{~B}$ & $\mathrm{C}$ & $\mathrm{D}$ \\
\hline \multicolumn{5}{|l|}{ Dicotyledonous } \\
\hline 1. Viola arvensis Murray & 13.1 & 7.6 & 8.4 & 11.9 \\
\hline 2. Matricaria maritima subsp. inodora (L.) Dostál & 12.6 & 0.7 & 0.5 & 0.9 \\
\hline 3. Veronica arvensis $\mathrm{L}$. & 5.9 & 1.9 & 1.5 & 2.4 \\
\hline 4. Capsella bursa-pastoris (L.) Medik. & 4.3 & 0.1 & 0.1 & 0.1 \\
\hline 5. Geranium pusillum Burm. f. ex L. & 2.7 & 0.6 & 0.5 & 0.9 \\
\hline 6. Chenopodium album L. & 2.6 & - & - & - \\
\hline 7. Anthemis arvensis L. & 2.3 & 0.2 & 0.1 & 0.2 \\
\hline 8. Stellaria media (L.) Vill. & 1.6 & 0.1 & 0.1 & 0.3 \\
\hline 9. Galium aparine L. & 1.4 & 0.6 & 0.9 & 1.2 \\
\hline 10. Vicia hirsuta (L.) Gray & 1.2 & 0.1 & 0.2 & 0.1 \\
\hline 11. Myosotis arvensis (L.) Hill & 1.1 & 0.1 & 0.2 & 0.3 \\
\hline 12. Cerastium holosteoides Fr. Emend. Hyl. & 0.8 & - & - & - \\
\hline 13. Fallopia convolvulus (L.) Á. Löve & 0.6 & 1.0 & 0.9 & 0.6 \\
\hline 14. Conyza canadensis (L.) Cronquist & 0.4 & - & - & 0.1 \\
\hline 15. Spergula arvensis L. & 0.4 & - & - & - \\
\hline 16. Polygonum aviculare L. & 0.3 & 0.2 & 0.1 & 0.3 \\
\hline 17. Veronica persica Poir. & 0.3 & 0.0 & 0.1 & 0.1 \\
\hline 18. Lamium amplexicaule L. & 0.1 & - & 0.1 & 0.1 \\
\hline 19. Sonchus arvensis L. & 0.1 & - & - & - \\
\hline 20. Anchusa arvensis (L.) M. Bieb. & 0.1 & - & - & - \\
\hline 21. Raphanus raphanistrum L. & 0.1 & - & - & - \\
\hline 22. Gnaphalium uliginosum L. & 0.0 & - & - & - \\
\hline 23. Oxalis stricta $\mathrm{L}$. & 0.0 & - & - & - \\
\hline 24. Anagallis arvensis L. & - & - & - & 0.0 \\
\hline Total dicotyledonous & 52.0 & 13.2 & 13.7 & 19.5 \\
\hline Number of dicotyledonous species & 23 & 13 & 14 & 17 \\
\hline \multicolumn{5}{|l|}{ Monocotyledonous** } \\
\hline 25. Apera spica-venti (L.) P. Beauv. & 19.0 & 0.1 & 0.1 & 2.6 \\
\hline 26. Elymus repens (L.) Gould & 0.7 & 0.5 & 0.1 & 0.2 \\
\hline 27. Echinochloa crus-galli (L.) P. Beauv. & 0.0 & 0.3 & 1.9 & 0.0 \\
\hline 28. Роа аппиа $\mathrm{L}$. & 0.0 & 0.2 & 0.3 & 0.2 \\
\hline 29. Equisetum arvense L. & 0.0 & 0.0 & 0.0 & 0.0 \\
\hline Total monocotyledonous & 19.7 & 1.1 & 2.4 & 3.0 \\
\hline Number of monocotyledonous species & 2 & 4 & 4 & 3 \\
\hline Total number of weeds & 71.7 & 14.3 & 16.1 & 22.5 \\
\hline Number of species & 25 & 17 & 18 & 20 \\
\hline
\end{tabular}

0.0 - Species occurring in less than 0.1 per $\mathrm{m}^{2}$

- Species not occurring

* explanation like in table 1

** with Equisetum arvense L. 
Table 4

Species composition and the number of weeds per $1 \mathrm{~m}^{2}$ of $\mathrm{x}$ Triticale rimpaui Wittm. canopy before harvest in dependence on herbicide doses, mean figures in the years 2003-2005.

\begin{tabular}{|c|c|c|c|c|}
\hline \multirow{2}{*}{ Species } & \multicolumn{4}{|c|}{ Herbicide doses } \\
\hline & $* \mathrm{~A}$ & $\mathrm{~B}$ & $\mathrm{C}$ & $\mathrm{D}$ \\
\hline \multicolumn{5}{|l|}{ Dicotyledonous } \\
\hline 1. Chenopodium album $\mathrm{L}$. & 7.1 & 0.0 & 0.0 & 0.4 \\
\hline 2. Matricaria maritima subsp. inodora (L.) Dostál & 6.4 & 0.7 & 1.0 & 2.0 \\
\hline 3. Viola arvensis Murray & 3.7 & 5.2 & 6.0 & 9.4 \\
\hline 4. Fallopia convolvulus (L.) Á. Löve & 1.1 & 1.3 & 1.1 & 1.3 \\
\hline 5. Myosotis arvensis (L.) Hill & 1,1 & 0.6 & 0.4 & 1.4 \\
\hline 6. Geranium pusillum Burm. f. ex L. & 1.0 & 1.0 & 0.9 & 2.7 \\
\hline 7. Polygonum aviculare $\mathrm{L}$. & 0.7 & 1.6 & 0.9 & 1.4 \\
\hline 8. Stellaria media (L.) Vill. & 0.6 & 0.4 & 0.5 & 0.7 \\
\hline 9. Vicia hirsuta (L.) Gray & 0.6 & 0.1 & 0.1 & 0.4 \\
\hline 10. Conyza canadensis (L.) Cronquist & 0.6 & 0.3 & 0.0 & 0.2 \\
\hline 11. Galium aparine L. & 0.4 & 0.7 & 0.2 & 0.8 \\
\hline 12. Veronica arvensis $\mathrm{L}$. & 0.4 & 0.3 & 0.3 & 0.4 \\
\hline 13. Capsella bursa-pastoris (L.) Medik. & 0.4 & - & 0.0 & 0.0 \\
\hline 14. Oxalis stricta $\mathrm{L}$. & 0.2 & 0.3 & 0.3 & 1.2 \\
\hline 15. Anagallis arvensis L. & 0.2 & 0.0 & 0.3 & 0.7 \\
\hline 16. Spergula arvensis L. & 0.1 & - & - & - \\
\hline 17. Anthemis arvensis L. & 0.1 & 0.0 & 0.1 & 0.2 \\
\hline 18. Lamium amplexicaule $\mathrm{L}$. & 0.0 & - & - & - \\
\hline 19. Gnaphalium uliginosum L. & 0.1 & 0.3 & 0.1 & 0.1 \\
\hline 20. Gypsophila muralis L. & 0.1 & - & - & - \\
\hline 21. Anchusa arvensis (L.) M. Bieb. & 0.1 & - & - & - \\
\hline 22. Cerastium holosteoides Fr. Emend. Hyl. & 0.0 & 0.0 & 0.0 & 0.1 \\
\hline 23. Papaver rhoeas L. & 0.0 & - & - & 0.1 \\
\hline 24. Trifolium arvense $\mathrm{L}$. & 0.0 & - & - & - \\
\hline 25. Gnaphalium uliginosum L. & 0.0 & - & - & - \\
\hline 26. Artemisia vulgaris L. & 0.0 & - & - & - \\
\hline 27. Plantago major L. & - & 0.3 & 0.1 & 0.1 \\
\hline 28. Stachys palustris L. & - & 0.0 & 0.0 & - \\
\hline 29. Lapsana communis L.s.str. & - & 0.0 & - & 0.0 \\
\hline 30. Veronica persica Poir. & - & - & - & 0.0 \\
\hline 31. Centaurea cyanus L. & - & - & - & 0.0 \\
\hline Total dicotyledonous & 25.0 & 13.2 & 12.3 & 23.6 \\
\hline Number of dicotyledonous species & 25 & 20 & 20 & 23 \\
\hline \multicolumn{5}{|l|}{ Monocotyledonous } \\
\hline 32. Apera spica-venti (L.) P. Beauv. & 74.2 & 0.7 & 0.2 & 2.5 \\
\hline 33. Elymus repens (L.) Gould & 2.8 & 1.3 & 1.1 & 0.9 \\
\hline 34. Echinochloa crus-galli (L.) P. Beauv. & 0.9 & 8.5 & 4.5 & 5.4 \\
\hline 35. Setaria pumila (Poir.) Roem. \& Schult. & 0.0 & 2.2 & 4.6 & 1.8 \\
\hline 36. Роа аппиа $\mathrm{L}$. & - & 0.0 & - & - \\
\hline 37. Avena fatua $\mathrm{L}$. & - & - & - & 0.1 \\
\hline Total monocotyledonous & 77.9 & 12.7 & 10.4 & 10.7 \\
\hline Number of monocotyledonous species & 4 & 5 & 4 & 5 \\
\hline Total number of weeds & 102.9 & 25.9 & 22.7 & 34.3 \\
\hline Number of species & 29 & 25 & 24 & 28 \\
\hline
\end{tabular}

0.0 - Species occurring in less than 0.1 per $\mathrm{m}^{2}$

- Species not occurring; * explanation like in table 1 
Table 5

Species composition and the number of weeds per $1 \mathrm{~m}^{2}$ of $\mathrm{x}$ Triticale rimpaui Wittm. canopy at the first date weed infestation assessment in dependence on cultivars, mean figures in the years 2003-2005.

\begin{tabular}{|c|c|c|c|}
\hline Species & & Cultivar & \\
\hline Dicotyledonous & Janko & Woltario & Krakowiak \\
\hline 1. Viola arvensis Murray & 9.1 & 10.6 & 11.1 \\
\hline 2. Veronica arvensis $\mathrm{L}$. & 3.6 & 2.7 & 2.5 \\
\hline 3. Matricaria maritima subsp. inodora (L.) Dostál & 3.1 & 4.1 & 3.7 \\
\hline 4. Galium aparine L. & 1.4 & 1.0 & 0.8 \\
\hline 5. Fallopia convolvulus (L.) Á. Löve & 1.2 & 0.6 & 0.6 \\
\hline 6. Capsella bursa-pastoris (L.) Medik. & 0.9 & 1.2 & 1.4 \\
\hline 7. Geranium pusillum Burm. f. ex L. & 0.9 & 1.5 & 1.2 \\
\hline 8. Chenopodium album L. & 0.9 & 0.5 & 0.5 \\
\hline 9. Polygonum aviculare L. & 0.5 & 0.1 & 0.1 \\
\hline 10. Anthemis arvensis L. & 0.6 & 0.7 & 0.7 \\
\hline 11. Vicia hirsuta (L.) Gray & 0.6 & 0.5 & 0.1 \\
\hline 12. Stellaria media (L.) Vill. & 0.4 & 0.5 & 0.5 \\
\hline 13. Myosotis arvensis (L.) Hill & 0.3 & 0.4 & 0.4 \\
\hline 14. Veronica persica Poir. & 0.1 & 0.1 & 0.1 \\
\hline 15. Cerastium holosteoides Fr. Emend. Hyl. & 0.1 & 0.2 & 0.2 \\
\hline 16. Lamium amplexicaule $\mathrm{L}$. & 0.1 & 0.1 & 0.1 \\
\hline 17. Conyza canadensis (L.) Cronquist & 0.1 & 0.1 & 0.1 \\
\hline 18. Anchusa arvensis (L.) M. Bieb. & - & 0.0 & 0.1 \\
\hline 19. Spergula arvensis L. & 0.0 & 0.1 & 0.1 \\
\hline 20. Anagallis arvensis L. & 0.0 & - & - \\
\hline 21. Sonchus arvensis L. & - & - & 0.1 \\
\hline 22. Raphanus raphanistrum $\mathrm{L}$. & - & 0.0 & 0.1 \\
\hline 23. Gnaphalium uliginosum L. & - & 0.0 & - \\
\hline 24. Oxalis stricta L. & - & 0.0 & 0.0 \\
\hline Total dicotyledonous & 23.9 & 25.0 & 24.5 \\
\hline Number of dicotyledonous species & 19 & 22 & 22 \\
\hline \multicolumn{4}{|l|}{ Monocotyledonous* } \\
\hline 25. Apera spica-venti (L.) P. Beauv. & 6.1 & 4.6 & 5.8 \\
\hline 26. Echinochloa crus-galli (L.) P. Beauv. & 1.5 & 0.1 & 0.1 \\
\hline 27. Elymus repens (L.) Gould. & 0.3 & 0.2 & 0.6 \\
\hline 28. Poa annua L. & 0.2 & 0.1 & 0.2 \\
\hline 29. Equisetum arvense L. & 0.0 & - & - \\
\hline Total monocotyledonous & 8.1 & 5.0 & 6.7 \\
\hline Number of monocotyledonous species & 5 & 4 & 4 \\
\hline Total number of weeds & 32.0 & 30.0 & 31.2 \\
\hline Number of species & 24 & 26 & 26 \\
\hline
\end{tabular}

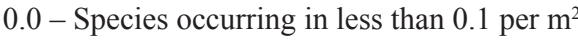

- Species not occurring

* with Equisetum arvense L. 
Table 6

Species composition and the number of weeds per $1 \mathrm{~m}^{2}$ of a $\mathrm{x}$ Triticale rimpaui Wittm. canopy before harvest in dependent on cultivars, mean figures in the years 2003-2005.

\begin{tabular}{|c|c|c|c|}
\hline Gatunki - Species & & Cultivar & \\
\hline Dicotyledonous & Janko & Woltario & Krakowiak \\
\hline 1. Viola arvensis Murray & 5.1 & 6.4 & 6.8 \\
\hline 2. Matricaria maritima subsp. inodora (L.) Dostál & 2.9 & 2.4 & 2.3 \\
\hline 3. Chenopodium album $\mathrm{L}$. & 1.3 & 2.6 & 1.8 \\
\hline 4. Geranium pusillum Burm. f. ex L. & 1.1 & 1.5 & 1.6 \\
\hline 5. Fallopia convolvulus (L.) Á. Löve & 1.0 & 1.3 & 1.3 \\
\hline 6. Polygonum aviculare $\mathrm{L}$. & 1.0 & 1.3 & 1.2 \\
\hline 7. Myosotis arvensis (L.) Hill & 0.7 & 1.1 & 0.8 \\
\hline 8. Stellaria media (L.) Vill. & 0.6 & 0.6 & 0.5 \\
\hline 9. Oxalis stricta $\mathrm{L}$. & 0.6 & 0.3 & 0.4 \\
\hline 10. Galium aparine L. & 0.3 & 0.6 & 0.5 \\
\hline 11. Veronica arvensis $\mathrm{L}$. & 0.3 & 0.3 & 0.4 \\
\hline 12. Conyza canadensis (L.) Cronquist & 0.3 & 0.3 & 0.2 \\
\hline 13. Vicia hirsuta (L.) Gray & 0.3 & 0.2 & 0.4 \\
\hline 14. Anagallis arvensis L. & 0.2 & 0.2 & 0.4 \\
\hline 15. Plantago major $\mathrm{L}$. & 0.2 & 0.2 & 0.0 \\
\hline 16. Gnaphalium uliginosum L. & 0.1 & 0.3 & 0.1 \\
\hline 17. Capsella bursa-pastoris (L.) Medik. & 0.1 & 0.1 & 0.2 \\
\hline 18. Anthemis arvensis $\mathrm{L}$. & 0.1 & 0.1 & 0.1 \\
\hline 19. Cerastium holosteoides Fr. emend. Hyl. & 0.1 & 0.0 & 0.1 \\
\hline 20. Gypsophila muralis L. & 0.1 & - & 0.0 \\
\hline 21. Lapsana communis L.s.str. & 0.0 & 0.0 & - \\
\hline 22. Stachys palustris L. & 0.0 & - & 0.0 \\
\hline 23. Anchusa arvensis (L.) M. Bieb. & 0.0 & - & 0.0 \\
\hline 24. Veronica persica Poir. & 0.0 & - & - \\
\hline 25. Spergula arvensis L. & - & 0.2 & - \\
\hline 26. Papaver rhoeas L. & - & 0.1 & 0.0 \\
\hline 27. Trifolium arvense $\mathrm{L}$. & - & 0.0 & - \\
\hline 28. Artemisia vulgaris L. & - & 0.0 & - \\
\hline 29. Centaurea cyanus L. & - & 0.0 & - \\
\hline Total dicotyledonous & 16.4 & 20.1 & 19.1 \\
\hline Number of dicotyledonous species & 24 & 25 & 23 \\
\hline \multicolumn{4}{|l|}{ Monocotyledonous } \\
\hline 30. Apera spica-venti (L.) P. Beauv. & 18.5 & 21.4 & 18.2 \\
\hline 31. Echinochloa crus-galli (L.) P. Beauv. & 5.3 & 5.4 & 3.9 \\
\hline 32. Setaria pumila (Poir.) Roem. \& Schult. & 4.3 & 1.5 & 0.6 \\
\hline 33. Elymus repens (L.) P. Beauv. & 1.4 & 1.6 & 1.6 \\
\hline 34. Avena fatua $\mathrm{L}$. & - & 0.1 & - \\
\hline 35. Pоа аппиа $\mathrm{L}$. & - & - & 0.0 \\
\hline Total monocotyledonous & 29.6 & 30.0 & 24.3 \\
\hline Number of monocotyledonous species & 4 & 5 & 5 \\
\hline Total number of weeds & 46.0 & 50.1 & 43.4 \\
\hline Number of species & 28 & 30 & 28 \\
\hline
\end{tabular}

0.0 - Species occurring in less than 0.1 per $\mathrm{m}^{2}$ - Species not occurring 
canopy of all winter triticale cultivars at both dates of weed infestation assessment. But among monocotyledonous species, the most numerous were Apera spicaventi and Echinochloa crus-galli (Tab. 5, Tab. 6). At the first assessment date, 24 weed species, including 19 dicotyledonous and 5 monocotyledonous ones, were found in the canopy of 'Janko' cv., whereas there were 22 dicotyledonous and 4 monocotyledonous species in the canopy of the other cultivars (Tab. 5). In the canopy of winter triticale 'Woltario' cv., 30 weed species, including 25 dicotyledonous ones, were found at the second assessment date, whereas in the canopy of the cultivars 'Janko' and 'Krakowiak' there were 28 species in each, including 24 and 23 dicotyledonous ones, respectively (Tab. 6).

\section{DISCUSSION}

At the first date of weed infestation assessment, the applied herbicides reduced the number of weeds from 68.6 to $80.1 \%$ and their air-dry mass from 84.0 to $93.0 \%$, compared to the herbicide untreated control. The total number of weeds estimated before triticale harvest was smaller by 66.7 to $77.9 \%$ compared to the control, and air-dry mass of weeds from 87.5 to $94.0 \%$. Worth noting is the fact that in the plot with the herbicide dose reduced to $75 \%$, at the second assessment date, both the number and air-dry mass of weeds were slightly smaller than in the other herbicide treated plots (Tab. 1). Differences between the herbicide treated plots were within the statistical error. Research conducted by Starczewski and Żądełek (2000) has shown that full doses of preparations reduced airdry mass of weeds, depending on the triticale cultivar, from $46 \%$ to $54 \%$ compared to the control.

The selection of winter triticale cultivars did not significantly affect the canopy weed infestation level. F e ledyn-S z ew c z y k and D u e r (2005), P a r y la k et al. (2006) and K r a s k a (2006) draw attention to the possibility of reducing the weed infestation level in cereals by selecting an appropriate cultivar.

At the first date of weed infestation assessment, the effectiveness of action of different herbicide doses, compared to the control, was from $9.2 \%$ to $42.0 \%$ in relation to Viola arvensis, Veronica arvensis from 59.3\% to $74.6 \%$, Matricaria maritima from $92.9 \%$ to $96.0 \%$, Capsella bursa-pastoris $97.7 \%$ and Apera spica-venti from $86.3 \%$ to $99.5 \%$. The efficacy of control of the most numerous weed species before triticale harvesting was 94.4\% for Chenopodium album, Matricaria maritima from 89.1 to $68.8 \%$ and Apera spica-venti from $96.6 \%$ to $99.7 \%$.

In their experiment, $\mathrm{R}$ o m e $\mathrm{k}$ and $\mathrm{Dz}$ i e $\mathrm{nia}$ (2000) confirm that decreased herbicide doses resulted in reduced effectiveness of control of Apera spica-ven- ti. They found in their research that the application of a full dose of the herbicides Protugan 500 SC, Lentipur 80 WP and Chisel 75 DF reduced Apera spica-venti, on the average, by $71 \%$ to $77 \%$. In turn, a reduction in the dose of the tested herbicides by $50 \%$ resulted in reduced effectiveness of control of the abovementioned weed by $16 \%$ to $31 \%$. Higher effectiveness of Apera spica-venti reduction was noted by $\mathrm{D}$ o $\mathrm{m}$ a r a d z k i et al. (2003), when applying Arelon Dispersion $500 \mathrm{SC}$ at a full dose and at doses reduced to $75 \%, 50 \%$ and $25 \%$. The preparation applied at a full dose reduced to a high extent $(99-100 \%)$ the occurrence of common windgrass, whereas lowered doses reduced Apera spicaventi to a slightly smaller extent (from 93\% to 99\%). Whiting et al. (1991) have found that it is possible to reduce the occurrence of dicotyledonous species and Apera spica-venti in cereals by the application of herbicides at reduced doses from 30 to $60 \%$. Also D a v i e s and W hit ing (1989), when applying herbicides containing isoproturon, did not find any differences in the effectiveness of control of Apera spica-venti between the full dose and the dose reduced to $50 \%$.

Adamczewski and Praczyk (1999) claim that Apera spica-venti poses the greatest risk to winter cereals among monocotyledonous weeds. It has found confirmation in the control of the experiment in question.

D o maradzki (2006) is of opinion that the main criterion deciding about the herbicide rate should be, in the first place, the condition and degree of weed infestation of a field. A weaker effect of reduced herbicide doses should be expected in winter cereals, in particular in triticale and barley, where these weeds are more advanced in development due to early sowing of these species. Moreover, lower doses have a weaker effect especially in cases of very high weed intensity in a crop canopy.

\section{CONCLUSIONS}

1. The weed infestation level of winter triticale canopy, measured both in terms of the number of individuals and air-dry mass of weeds, was not significantly differentiated by the applied doses of herbicides. It indicates the possibility of reducing herbicide doses in the winter triticale canopy without the risk of increasing the weed infestation level. A tendency towards the occurrence of a larger number of individuals and higher air-dry mass of weeds was only found in the plots with the herbicide dose reduced by half compared to the other herbicide treated plots.

2. Before winter triticale harvesting, a larger number of weed species was found in all the plots assessed. Viola arvensis, Matricaria maritima, Chenopodium album and Apera spica-venti were the dominant 
species in the winter triticale canopy at both dates of weed infestation assessment.

3. At both dates of weed infestation assessment, the applied herbicides reduced the occurrence of Matricaria maritima, Chenopodium album and Apera spica-venti to the largest extent.

4. The selection of cultivars did not significantly affect the weed infestation level of winter triticale canopy.

\section{REFERENCES}

Adamczewski K., 2000. Weed control method development and perspectives of reduction of weed density. Post. Ochr. Roślin, 40 (1): 101-112.

Adamczewski K., Praczyk T., 1999. Strategy of weed control in small grain cereals. Pam. Puł. 114: 5-13.

Badowski M., Domaradzki K., Filipiak K., Franek M., Gołębiowska H., Kieloch., Kucharski M., Rola H., Rola J., Sadowski J., Sekutowski T., Zawerbny T., 2001. Metodyka doświadczeń biologicznej oceny herbicydów, bioregulatorów i adiuwantów. Cz. 1 doświadczenia polowe. / Experimental methodology of biological assessment of herbicides, bioregulatotrs and adjuvants. Part 1. Field experiment. Wydawnictwo IUNG.

Davies D. H. K., Whiting A. J., 1989. Yield responses to herbicide use and weed levels in winter wheat and spring barley in scotish trials and consequences for economic models. The BCPC Conference - Weeds, 3, 955-960.

Domaradzki K., 2006. Effectiveness of the weed control in cereals in the aspect of reducing herbicide doses and selected agroecological factors. Monografie i Rozprawy Naukowe, Puławy, 17: 5-111.

Domaradzki K., Rola H., 1999. Regulation of degree of weed infestation in cereals with use of reduction herbicide doses. Pam. Puł. 114: 63-71.

Domaradzki K., Rola H., 2000. The effect of application of reduced herbicide rates in cereals. Pam. Puł., 120/I: 53-64.

Domaradzki K., Rola H., 2001. Ecological and agronomic aspects of application lower rates of herbicides in regulation of weed infestation in cereals. Post. Ochr. Roślin, 41 (1): 229-239.

Domaradzki K., Sadowski J., 2002. The possibility of reduction of load for natural environment by applying the herbicides in limited doses. Pam. Puł. 130/I: 99-114.

Domaradzki K., Rola H., 2004. Efficacy of reduced doses of amidosulfuron, fluroxypyr and tribenuron-methyl against Anthemis arvensis, Chenopodium album and Galium aparine. 12th International Conference on Weed Biology, Ann. AFPP: 543-548.

Feledyn-Szewczyk B., Duer I., 2005. The competitiveness of some winter wheat varieties cultivated in organic crop production system due to weeds. Post. Ochr. Roślin, 45 (1): 126-133.
Kraska P., 2006. The influence of different herbicides doses on winter wheat weed infestation. Post. Ochr. Roślin, 46 (2): 256-260.

Parylak D., Zawieja J., Jędruszczak M., StupnickaRodzynkiewicz E., Dąbkowska T., Snarska K., 2006. Use of the mixed crops, cultivar properties or allelopathy in weed control. Post. Ochr. Roślin, 46 (1): 33-52.

Proven M. J., Courtney A., Picton J., Davies D. H. K., Whiting A. J., 1991. Cost-effectiveness of weed control in cereals - system based on thresholds and reduced rates of herbicides. The BCPC Conference - Weeds, 3: 1201-1208.

Rola J., Domaradzki K., Nowicka B., 1997. The results of research on reduction of herbicide doses for weed control in cereals. Post. Ochr. Roślin, 37 (1): 82-87.

Romek B., Dzienia S., 2000. Efficacy of applying full land reduced doses of herbicides in winter triticale. Ann. UMCS, sect. E, 55, Suppl. 22: 181-186.

Starczewski J., Żądełek J., 2000. Effect of quantity of seeding and reduction of doses of herbicides on weed infestation and yielding of triticale. Ann. UMCS, sect. E, 55, Suppl. 22: 187-195.

Streibig J. C., 1989. The herbicide dose-response curie and the economics of weed control. The BCPC Conference - Weeds, 3: 927-953.

Whiting A. J., Davies D. H. K., Brown H., Whytock G., 1991. The field use of reduced doses of broad-leaved weed herbicides in cereals. The BCPC Conference - Weeds, 3: 1209-1216.

\section{Wpływ zróżnicowanych dawek herbicydów na zachwaszczenie pszenżyta ozimego uprawianego w monokulturze}

\section{Streszczenie}

Badania przeprowadzono w latach 2003-2005 w Gospodarstwie Doświadczalnym Bezek niedaleko Chełma. W dwuczynnikowym doświadczeniu przeprowadzonym $\mathrm{w}$ układzie bloków losowanych porównywano działanie trzech dawek herbicydów w pszenżycie ozimym odmian 'Janko', 'Woltario' i 'Krakowiak' uprawianych w monokulturze. Herbicydy były stosowane w pełnych zalecanych dawkach, zredukowanych do $75 \%$ i do $50 \%$. Kontrolę stanowiły poletka na których nie stosowano herbicydów. W pracy oceniono poziom zachwaszczenia łanu (liczba osobników, skład gatunkowy i powietrznie sucha masa) pszenżyta ozimego w 6 tygodni po zastosowaniu herbicydów Atlantis 04 WG i Factor 365 EC oraz przed zbiorem.

Poziom zachwaszczenia łanu pszenżyta ozimego mierzony zarówno liczbą osobników jak i powietrznie suchą masą chwastów nie był istotnie różnicowany przez zastosowane dawki herbicydów. Uzyskane 
wyniki wskazują na możliwość obniżenia dawek herbicydów w łanie pszenżyta ozimego bez ryzyka wzrostu poziomu zachwaszczenia. Dobór odmiany pszenżyta ozimego nie zmieniał poziomu zachwaszczenia łanu.
Gatunkami dominującymi w łanie pszenżyta ozimego w obu terminach oceny zachwaszczenia były Viola arvensis, Matricaria maritima, Chenopodium album oraz Apera spica-venti. 